\title{
THE EFFECT OF MACROECONOMIC AND RISK FACTORS TOWARDS STOCK RETURN OF INDONESIA INDUSTRIAL SECTOR IN 2008 TO 2015
}

\author{
Gunawan Martin*, Tanusdjaja Hendang, Ruslim Herman \\ Faculty of Economics, Tarumanagara University, Jakarta, Indonesia \\ *E-mail: margun 87@yahoo.com
}

\begin{abstract}
The study about stock is to determine whether risk and macroeconomic factors can affect stock return in a population of all industrial sectors in Indonesia. The stock investment does not save money in a short-run, and then expect immediate return, but it is also a long-run investment which should be analyzed using good business model. However, behind the capital market development, people are still more interested in using money for operational activities than for an investment. Moreover, they think that it is more beneficial to invest for saving than for stock because the percentage of interest offered to customers is definitely higher than the return stock's. In this study, multiple regression method in Eviews 8 is used. Besides, the variables consisting of non-systematic risk variable involving beta stock and macroeconomic variable involving inflation, interest, and exchange rate are involved in the hypothesis model to answer whether there is an effect of the variables as a stock return estimator during 2008 to 2015. From 259 issuer samples in all sectors, it is found that the macroeconomic variable changes can simultaneously explain the fluctuation of stock return. The result of each specific sector shows that stock return can be predicted using exchange rate, inflation, and interest.
\end{abstract}

\section{KEY WORDS}

Macro-economy, risk, stock return, industrial sector.

Indonesia is a country which has adapted the capital market of Netherlands since 1912, but its condition and form of capital market are still young (Steven, 2013). The capital market products are able to give return from high investment which is not similar to other markets in Asia, America, and Europe (Jogiyanto, 2003); thus, the products of Indonesian capital market are more hunted and run by foreign investors than locals (Sulistio, 2016). In the twenty-fifth, Indonesia Stock Exchange (IDX) had showed investment's products in the capital market, such as portfolio, mutual fund, and bond. However, a problem appeared in the capital market was that when the products were launched in the exchange market, they were not fully understood by people who majority have low information about capital market (Merawati and Putri, 2016).

The main point is that a good investor will realize that stock investment does not save money in a short-run, and then expect immediate return, but it is a long-run investment which should be analyzed using good business model. As a funding feature and funding management, capital market has produced blue chip Company in its development. However, behind the capital market development, people are more interested in spending money for operational activities than for investment. Moreover, they think that saving investment is more beneficial than stock because the percentage of interest offered for customers is definitely higher than stock return (Kusmawati, 2011).

Besides those concepts, the quality of investors run in the capital market tend to be trader-like and follow people who analyze of negative price and short-run expectation which value is small but in a big quantity to be able to get stock return (Cooper, 2013). These investors prefer investing low price in stock split event, but they are placed in high-liquidity corporations as a hedging concept to protect their money while investing (Ahmad and Halim, 2014; Gomez and Yague, 2005).

There are a lot of studies conducted in Indonesia to find out any factors affecting the stock movement. Practitioners of fundamental and technical investor analysis have described some ways to predict the value of stock in certain period and pattern. Their analyses are: the 
analysis of market reaction towards a portfolio in a form of hypothetical market and stock risk (Jemmy, 2012; Mutiara, 2012; Nurhayanto, 2011), the analysis of stock towards macroeconomic condition, events and its country development (Adtyara, 2012), and the progress of company's performance in generating stock return for its investors (Indayani and Yahya, 2013). They are some examples of stock analysis research which are conducted to find out predictors of stock movement. The book-to-market performance ratio can predict return and risk of cash flow uncertainty which can produce predictor return (Lewellen, 2000). The interest rates, the number of spread between high and low obligation, and dividend rate can predict time variation from expected return (Fama et al., 1977; Keim and Stambaugh, 1986; Fama et al., 1898; Kothari and Shanken, 1997)

The concept of this research is obtained by the writer from the various results of previous studies in predicting stock return in Indonesia. In 2004 to 2008, stock return was not affected by liquidity, profitability, and dividend in LQ45 index (Deitiana, 2011). In 2008 to 2013, the cash flow and profit development simultaneously affected stock returns in hundreds manufacture companies in Indonesia Stock Exchange (Uluipuli, 2007; Suhemi, 2015; Ginting, 2011). It is found that the cash flow of funding activities which affected stock abnormal return was on the manufacture population in 2008 to 2011 (Nelvianti, 2013). During 2011 to 2014, profitability affected return, whereas growth and liquidity did not affect the return of 116 companies of property and real estate sectors (Anggrahini and Priyadi, 2016).

Based on the results of previous studies, the writer was inspired to make this research which purpose is to answer problems obtained from difference findings using macroeconomic and risk variable. Besides, the writer wants to know whether macroeconomics and risk affect stock return in 2008 to 2015 . It is expected that the benefits of this study can contribute knowledge relating to some factors which can predict the price of stock of industrial sectors in Indonesia investment.

\section{METHODS OF RESEARCH}

The characteristic used by the writer in this study is purposive sampling method with applied research design (Nasution and Usman, 2007), a kind of research used to answer problems, and then use the result of the study in the following implementation. Then, it is obvious that the explanation used in this study is qualitative and quantitative method (Nachrowi and Usman, 2006). The variables of this research are: 1) Stock return measured from the stock price in year one to the previous year; 2) Stock beta or systematic risk of company measured from the covariant and variant per issuer; 3 ) The rate of three-month interest rate from Jakarta Interchange Bank Offer Rate (JIBOR); 4) The median rates of Rupiah towards USD by Bank of Indonesia, and 5) The percentage of inflation measured from Consumer Price Index by Central Bureau Statistics. The analysis of financial report content is used to obtain index from the research variables.

The writer collected data population of dependent variables from 505 issuers registered from each Indonesian industrial sector. The scope of the years in this research is limited to information about interest rate from JIBOR which was available on www.bi.go.id in 2008 to 2015. The survived issuers during this research were 259 issuers or about $51.29 \%$ who was then used as the samples of this study. The framework of research variables and hypothesis about the relationship between variables and research models is figured and formulated as the following.

$$
\operatorname{STPR}=a+\beta 1 \mathrm{BETA}+\beta 2 \mathrm{INFL}+\beta 3 \mathrm{EXCR}+\beta 1 \mathrm{INTR}+\mathrm{e}
$$

Where:

$$
\begin{aligned}
& \text { STPR }=\text { Stock return } \\
& \text { BETA = Stock beta } \\
& \text { INTR = Interest rate } \\
& \text { INFL = Inflation rate } \\
& \text { EXCR = Exchange rate }
\end{aligned}
$$


The writer uses Eview 8 with dated panel (Gujarati, 2004) as the test device and format of analysis from monthly data of monthly research variables. The analysis of multiple linear regression equation with least square model least and spurious-testing analysis are done in all research models. The data analysis are done to answer problems in which: 1) the regression on the model is to know that all variables simultaneously affect return in all industrial sectors; 2) the regression in each industrial sector model is done to know more details about the specificity and characteristics of the research variables in each sector.

\section{RESULTS OF STUDY}

Investing decision of an investor can be motivated by his understanding towards investment ranging from the type of investment, returns to be gained, risks encountered, to other matters related to the investment itself. Knowledge about investment can be obtained from anywhere, such as formal education including in college and non-formal education including training (Sharpe, 2005). Investors should know that stock investment can be done by knowing stock market information reflected by good corporate governance (Rahmawati and Handayani, 2017) and commitment from current funding sources by expecting greater future funding sources (Bodie et al, 2004) and to know macro and micro risk factors influencing stock, such as economic growth, inflation, exchange rate, capital structure, and asset levels (Maga et al, 2016).

Table 1 - Research Sectors

\begin{tabular}{llll}
\hline Sector & Issuer & Total Issuer & Coverage \\
\hline Trade, Service and Investment & 53 & 126 & $58 \%$ \\
Finance & 47 & 84 & $44 \%$ \\
Basic Industry and Chemistry & 39 & 68 & $43 \%$ \\
Various Industry & 29 & 38 & $24 \%$ \\
Consumption goods Industry & 26 & 40 & $35 \%$ \\
Property and Real Estate & 25 & 63 & $60 \%$ \\
Utilities and Transportation Infrastructure & 20 & 60 & $67 \%$ \\
Mining & 15 & 42 & $64 \%$ \\
Agriculture & 5 & 15 & $67 \%$ \\
\hline Total & 259 & 536 & $52 \%$ \\
\hline
\end{tabular}

Based on the research samples in Table 1, the trade and service industrial sector from 2008 to 2015 (production and consumption goods, hotels, restaurants, and tourisms, and printings) and finance sector are industries with the largest entity in Indonesia and for the infrastructure, property, mining, and agriculture sector, they have the highest data coverage on Indonesia Stock Exchange in this research. From the data, retail sector or consumption goods industry is the industrial sector with the lowest number of issuer coverage in this study (surviving from 2008 to 2015).

However, in reality, the consumption goods sector, such as food and beverage, pharmacy, cosmetics and household goods, household appliances and tobacco dominate the stock market which indicates that the majority of every issuer is engaged in those industries because they are profitable, having high stock value, and the sectors are mostly demanded by business owners to establish business and by investors to invest their capital. The finance sector, such as banks, securities market and its financing is also a sector with the largest number of issuer companies although it is not a sector with the highest stock value.

An industrial sector in Indonesia having the highest stock return in exchange is consumption goods sector which the average growth of stock returns reaches 6.1 times of 2.455 becoming 17.465 . In this sector, the developments of stock return are highly increase and steep from the increasing development as much as $6 \%$ up to $186 \%$ in 2008 to 2014 . The in each industrial sector of Indonesia can be seen in table 2 above. The stock returns in industrial sectors in Indonesia have the development average which is increasing during the years of the research. The average of stock return development in each industrial sector in Indonesia can be seen in the Table 2. 
Table 2 - The Average of Stocks of Each Industrial Sector in 2008 to 2015

\begin{tabular}{lllllllll}
\hline Industrial sector & 2008 & 2009 & 2010 & 2011 & 2012 & 2013 & 2014 & 2015 \\
\hline Consumption goods Industry & 2,455 & 3,395 & 9,726 & 12,884 & 18,025 & 25,239 & 26,697 & 17,465 \\
Agriculture & 3,866 & 3,934 & 4,675 & 4,718 & 4,547 & 4,163 & 5,374 & 4,237 \\
Mining & 1,535 & 1,435 & 1,877 & 2,006 & 1,644 & 1,302 & 1,352 & 901 \\
Utilities and Transportation Infrastructure & 813 & 721 & 760 & 713 & 790 & 857 & 892 & 909 \\
Finance & 624 & 728 & 1,145 & 1,375 & 1,494 & 1,694 & 2,005 & 2,020 \\
Basic Industry and Chemistry & 611 & 633 & 883 & 1,084 & 1,225 & 1,392 & 1,378 & 1,186 \\
Various Industry & 428 & 405 & 719 & 1,132 & 1,358 & 1,380 & 1,368 & 1,157 \\
Trade, Service and Investment & 360 & 368 & 515 & 766 & 1,065 & 1,147 & 1,236 & 1,188 \\
Properties and Real Estate & 339 & 323 & 370 & 550 & 741 & 1,339 & 1,590 & 1,636 \\
\hline Average & 832 & 935 & 1,796 & 2,305 & 2,951 & 3,791 & 4,062 & 3,033 \\
\hline
\end{tabular}

Source: Researcher data (2017).

The writer's analysis about the rising of stock return of consumption goods sector is explained from the addition of retail outlets in Indonesia, either it is in whole seller or franchise and small retail located around housing and settlement which support the distribution of products and increasing company's financial performance in this sector, excluding the economic condition. The agricultural sector in the post-crisis in 2008 had received subvention from the government by adjusting the State Budget in 2009. In the finance sector, the slackening business activities and widespread termination of employment increase the bank of non-performing loan, and in the future, it will hold banks in disbursing credit (Tjahjono et. al., 2009).

The downward movement of the mining sector's stock return shows that Indonesia's mining sector consisting of coal, oil and gas, metals and minerals and other subsectors has declining stock price from 2012 to 2015 . One of the explanations of the stock sector declining was caused by Constitution No. 4 in 2009 about minerals and coals without special treatment within 4 years which required each sector entrepreneur of mining to build mineral purification construction or smelter to produce processed-products before selling it to the international market (non-raw export).

The utility and transportation infrastructure sector with energy subsector have increased because of raising export, transportation subsector having raising stock return in 2012 to 2015; one of them is caused by technological advances in global positioning system increasing the needs of transportation. On the other hand, the real estate sector is the sector with the lowest stock return due to the fundamental factor of its industrial sector is the sector which tends to keep the solvability more than the liquidity, have capitalization and high expansion, and move in long-run context. From the nature of business, the stock of property industry is the lowest stock among all sectors.

Table 3 - Indonesia Inflation Rate in 2008 to 2015

\begin{tabular}{lllllllll}
\hline Period & 2008 & 2009 & 2010 & 2011 & 2012 & 2013 & 2014 & 2015 \\
\hline January & $158.3 \%$ & $113.8 \%$ & $118.0 \%$ & $126.3 \%$ & $130.9 \%$ & $136.9 \%$ & $111.0 \%$ & $118.7 \%$ \\
February & $159.3 \%$ & $114.0 \%$ & $118.4 \%$ & $126.5 \%$ & $131.0 \%$ & $137.9 \%$ & $111.3 \%$ & $118.3 \%$ \\
March & $160.8 \%$ & $114.3 \%$ & $118.2 \%$ & $126.1 \%$ & $131.1 \%$ & $138.8 \%$ & $111.4 \%$ & $118.5 \%$ \\
April & $161.7 \%$ & $113.9 \%$ & $118.4 \%$ & $125.7 \%$ & $131.3 \%$ & $138.6 \%$ & $111.4 \%$ & $118.9 \%$ \\
May & $164.0 \%$ & $114.0 \%$ & $118.7 \%$ & $125.8 \%$ & $131.4 \%$ & $138.6 \%$ & $111.5 \%$ & $119.5 \%$ \\
June & $110.1 \%$ & $114.1 \%$ & $119.9 \%$ & $126.5 \%$ & $132.2 \%$ & $140.0 \%$ & $112.0 \%$ & $120.1 \%$ \\
July & $111.6 \%$ & $114.6 \%$ & $121.7 \%$ & $127.4 \%$ & $133.2 \%$ & $144.6 \%$ & $113.1 \%$ & $121.3 \%$ \\
August & $112.2 \%$ & $115.3 \%$ & $122.7 \%$ & $128.5 \%$ & $134.4 \%$ & $146.3 \%$ & $113.6 \%$ & $121.7 \%$ \\
September & $113.3 \%$ & $116.5 \%$ & $123.2 \%$ & $128.9 \%$ & $134.5 \%$ & $145.7 \%$ & $113.9 \%$ & $121.7 \%$ \\
October & $113.8 \%$ & $116.7 \%$ & $123.3 \%$ & $128.7 \%$ & $134.7 \%$ & $145.9 \%$ & $114.4 \%$ & $121.6 \%$ \\
November & $113.9 \%$ & $116.7 \%$ & $124.0 \%$ & $129.2 \%$ & $134.8 \%$ & $146.0 \%$ & $116.1 \%$ & $121.8 \%$ \\
December & $113.9 \%$ & $117.0 \%$ & $125.2 \%$ & $129.9 \%$ & $135.5 \%$ & $146.8 \%$ & $119.0 \%$ & $123.0 \%$ \\
\hline Average & $132.73 \%$ & $115.06 \%$ & $120.97 \%$ & $127.45 \%$ & $132.90 \%$ & $142.18 \%$ & $113.22 \%$ & $120.42 \%$ \\
\hline
\end{tabular}

Source: Central Bureau of Statistics: Percentage of Consumer Price Index 2008-2015.

The Indonesian inflation movement summarized in Table 3 resembles the wave which 
increases to the point in May 2008 reaching $164.01 \%$, decreases in the next month, and continue to increase to the highest peak in 2013 before declining in 2014. This inflation volatility was caused by the rising of world oil and fuel price. The rising inflation in 2008 was also caused by rising world food commodity price (Kompas, July 25,2008 ) and raising volume of vehicles (Darmadi, 2011; Gunawan, 2014). The condition of global economic crisis in 2008 occurred in Indonesia was preceded by a subprime mortgage or crisis of low-quality housing loan in the United States, corporate bankruptcies, such as Lehman Brothers and AIG (Sugema, 2012).

In Indonesia, the inflation is triggered by the decline of the balance of trade due to the low rate of Indonesia exports. Inflation began to creep down to the lowest point in June 2008 to 2013. By the end of 2013 , the highest inflation was $146.8 \%$ which was caused by the rising fuel and electricity price (Bagi, 2017). The decline in inflation after its peak in 2013 came after the government implemented an accelerated quota of imports from products with declining price, such as meat and spices (Jacobs, 2013).

The development of inflation is in line with the development of Indonesian exchange rate. The exchange rate of rupiah towards US dollar as the exchange rate becomes the benchmark of the majority of companies and economic trade in Indonesia. The average exchange rates which increased from January 2009 to 2013 were a form of currency stability protection towards the price of goods and services as well as the stability towards other currencies. The first aspect was reflected in the development of the inflation rate, while the second aspect was reflected in the development of the rupiah exchange rate towards other currencies.

Table 4 - The Rates of Rupiah Exchange Rate towards United States Dollar in 2008 to 2015

\begin{tabular}{lllllllll}
\hline Period & 2008 & 2009 & 2010 & 2011 & 2012 & 2013 & 2014 & 2015 \\
\hline January & $9,406.35$ & $11,167.21$ & $9,275.45$ & $9,037.38$ & $9,109.14$ & $9,687.33$ & $12,179.65$ & $12,579.10$ \\
February & $9,181.15$ & $11,852.75$ & $9,348.21$ & $8,912.56$ & $9,025.76$ & $9,686.65$ & $11,935.10$ & $12,749.84$ \\
March & $9,184.94$ & $11,849.55$ & $9,173.73$ & $8,761.48$ & $9,165.33$ & $9,709.42$ & $11,427.05$ & $13,066.82$ \\
April & $9,208.64$ & $11,025.10$ & $9,027.33$ & $8,651.30$ & $9,175.50$ & $9,724.05$ & $11,435.75$ & $12,947.76$ \\
May & $9,290.80$ & $10,392.65$ & $9,183.21$ & $8,555.80$ & $9,290.24$ & $9,760.91$ & $11,525.94$ & $13,140.53$ \\
June & $9,295.71$ & $10,206.64$ & $9,148.36$ & $8,564.00$ & $9,451.14$ & $9,881.53$ & $11,892.62$ & $13,313.24$ \\
July & $9,163.45$ & $10,11 ., 33$ & $9,049.45$ & $8,533.24$ & $9,456.59$ & $10,073.39$ & $11,689.06$ & $13,374.79$ \\
August & $9,149.25$ & $9,977.60$ & $8,971.76$ & $8,532.00$ & $9,499.84$ & $10,572.50$ & $11,706.67$ & $13,781.75$ \\
September & $9,340.65$ & $9,900.72$ & $8,975.84$ & $8,765.50$ & $9,566.35$ & $11,346.24$ & $11,890.77$ & $14,396.10$ \\
October & $10,048.35$ & $9,482.73$ & $8,927.90$ & $8,895.24$ & $9,597.14$ & $11,366.90$ & $12,144.87$ & $13,795.86$ \\
November & $11,711.15$ & $9,469.95$ & $8,938.38$ & $9,015.18$ & $9,627.95$ & $11,613.10$ & $12,158.30$ & $13,672.57$ \\
December & $11,324.84$ & $9,457.75$ & $9,022.62$ & $9,088.48$ & $9,645.89$ & $12,087.10$ & $12,438.29$ & $13,854,60$ \\
\hline Average & $9,692.11$ & $10,407.83$ & $9,086.85$ & $8,776.01$ & $9,384.24$ & $10,459.09$ & $11,868.67$ & $13,389.41$ \\
\hline
\end{tabular}

Source: Bank of Indonesia: The average Rupiah Exchange Rate towards United States Dollar in 2008-2015.

Table 4 shows the interest rate of Bank of Indonesia in 2008 was the highest interest rate which average was $9.37 \%$; it was a form of government policy to anticipate crisis and reflect actual credit condition. Its increase was the government response towards the economic crisis and high interest rates from other debt instruments. The decline of the highest interest rate after 2008 was government's policy to change the reference of loan savings in Indonesia.

In relation to the research, the interest rate which can be measured by interest rate of Bank of Indonesia, JIBOR, as well as the percentage of bond interest loan as a product of capital market is the fluctuated research variable (Mutiara, 2012; Pangemanan, 2013). The interest rate set by the government from Bank of Indonesia is macroeconomic variable described in Table 5 as a variable with high volatility, and then adjusted to the movement of loans and deposits based on the interest rate of Bank of Indonesia certificate.

Systematic risk of the industrial sectors in 2008 had an average value below one (average stock beta 0.45 ) indicating the company's defensive stock movement, and it did not follow the movement of Jakarta Composite Index $(\mathrm{JCl})$ during the economic crisis. Companies were not responsive towards the $\mathrm{JCl}$ which began to rise up after the economic crisis in 2009 to 2011, especially agricultural sector with beta value above one. The measurement method of stock beta (Sarumaha, 2015) in the study is a variable in a company which can be affected by macroeconomic variable and corporate fundamentals. 
Table 5 - The Movement of Interest Rate of Indonesia in 2008 to 2015

\begin{tabular}{lllllllll}
\hline Period & 2008 & 2009 & 2010 & 2011 & 2012 & 2013 & 2014 & 2015 \\
\hline Jan & $7.99 \%$ & $10.68 \%$ & $6.71 \%$ & $6.28 \%$ & $4.46 \%$ & $4.23 \%$ & $6.63 \%$ & $6.26 \%$ \\
Feb & $7.97 \%$ & $9.42 \%$ & $6.69 \%$ & $6.09 \%$ & $4.14 \%$ & $4.60 \%$ & $7.82 \%$ & $6.10 \%$ \\
Mar & $7.98 \%$ & $8.87 \%$ & $6.67 \%$ & $6.67 \%$ & $3.80 \%$ & $4.16 \%$ & $7.53 \%$ & $6.29 \%$ \\
Apr & $8.00 \%$ & $8.40 \%$ & $6.57 \%$ & $6.54 \%$ & $3.80 \%$ & $4.59 \%$ & $7.22 \%$ & $6.21 \%$ \\
May & $8.21 \%$ & $7.95 \%$ & $6.48 \%$ & $6.90 \%$ & $3.72 \%$ & $4.36 \%$ & $6.48 \%$ & $5.91 \%$ \\
Jun & $8.66 \%$ & $7.43 \%$ & $6.51 \%$ & $6.25 \%$ & $4.42 \%$ & $4.56 \%$ & $7.84 \%$ & $6.29 \%$ \\
Jul & $9.25 \%$ & $7.10 \%$ & $6.50 \%$ & $6.86 \%$ & $4.52 \%$ & $5.45 \%$ & $7.35 \%$ & $6.10 \%$ \\
Aug & $9.54 \%$ & $6.79 \%$ & $6.50 \%$ & $5.34 \%$ & $3.84 \%$ & $5.15 \%$ & $7.67 \%$ & $6.62 \%$ \\
Sep & $10.36 \%$ & $6.71 \%$ & $6.47 \%$ & $5.40 \%$ & $4.63 \%$ & $6.75 \%$ & $7.44 \%$ & $7.02 \%$ \\
Oct & $11.26 \%$ & $6.72 \%$ & $6.41 \%$ & $5.58 \%$ & $4.41 \%$ & $6.37 \%$ & $7.03 \%$ & $7.65 \%$ \\
Nov & $11.70 \%$ & $6.72 \%$ & $6.30 \%$ & $5.18 \%$ & $4.18 \%$ & $6.89 \%$ & $6.79 \%$ & $8.23 \%$ \\
Dec & $11.49 \%$ & $6.74 \%$ & $6.24 \%$ & $4.75 \%$ & $3.97 \%$ & $6.75 \%$ & $6.05 \%$ & $7.21 \%$ \\
\hline Average & $9.37 \%$ & $7.79 \%$ & $6.50 \%$ & $5.99 \%$ & $4.16 \%$ & $5.32 \%$ & $7.15 \%$ & $6.66 \%$ \\
\hline
\end{tabular}

Source: Bank of Indonesia: JIBOR quarterly 2008-2015.

The stock beta of each industrial sector during 2008 to 2015 can be seen in Table 6 .

Table 6 - Beta Stock of Indonesian Industrial Sector 2008 to 2015

\begin{tabular}{lllllllll}
\hline Sector & 2008 & 2009 & 2010 & 2011 & 2012 & 2013 & 2014 & 2015 \\
\hline Various Industry & -0.49 & 0.99 & 0.55 & 0.78 & 0.17 & 0.02 & 1.15 & -0.89 \\
Consumption goods Industry & -0.45 & 0.86 & 0.70 & 1.20 & 1.03 & 0.20 & 1.47 & -0.68 \\
Basic and Chemical Industry & -0.34 & 0.91 & 0.61 & 0.68 & 0.51 & -0.01 & 1.75 & -0.65 \\
Utilities and Transportation Infrastructure & -0.41 & 0.56 & 0.48 & 0.50 & 0.53 & -0.24 & 2.80 & -1.18 \\
Finance & -0.49 & 0.94 & 1.03 & 0.73 & 0.78 & 0.00 & 2.67 & -0.69 \\
Trade, Service and Investment & -0.49 & 0.99 & 0.76 & 0.83 & 0.67 & 0.05 & 1.10 & -0.70 \\
Mining & -0.39 & 0.92 & 0.67 & 0.55 & -0.03 & 0.19 & 0.69 & -0.85 \\
Agriculture & -0.42 & 1.27 & 1.05 & 1.08 & 0.75 & 0.28 & 0.62 & -0.19 \\
Property and Real Estate & -0.50 & 1.05 & 0.61 & 0.54 & 0.87 & 0.01 & 3.00 & -0.66 \\
\hline Average & -0.45 & 0.93 & 0.72 & 0.75 & 0.61 & 0.03 & 1.81 & -0.74 \\
\hline
\end{tabular}

Source: Bank of Indonesia: quarterly JIBOR from year 2008-2015.

The results of research model from all sectors are as the following:

Stock Return $=-0.89183+0.063672$ BETA $-1,544872$ INFL -8.0300005 EXCR + 19.24832 INTR + 3.765577

In all sectors, the significant relationship that affects stock return is beta in positive and inflation in negative. Research model on all sectors have Rsquare value as much as $44.29 \%$, and based on $\mathrm{F}$ test, the value is. 007148 showing that independent variable simultaneously and partially influence the stock return. From the result, there is a significant correlation between each inflation and systematic risk variable towards the stock return across all industrial sectors in 2008 to 2015. The research model has met the requirements as an estimator without spurious relationship in which Durbin Watson value obtained from the equation is 1.999 which is greater than the R-square.

The explanation of this result also mentions that the predictor of the stock return is $55.71 \%$ by other factors, such as company's financial performance, trading volume, cash flow, and other non-financial factors, such as corporate reputation, auditor, or public ownership. From the result of this study, it can be explained that macroeconomic and non-systematic risk factors can affect stock returns during 2008 to 2015 . Macroeconomic factors, such as inflation, interest, exchange rates and systematic risk simultaneously affect the return of company's stock.

In specific sector test, the significance test of the research model ( $F$ test) and significant variable test ( $T$ test) show that in each industrial sector during 2008 to 2015, all independent variables in the model simultaneously affect stock return. The summary of equation test result in each sector is presented as the following. 
Table 7 - All sector and Specific Sector Test Result

\begin{tabular}{lllll}
\hline Sector & R-square & F Test & $\begin{array}{l}\text { Significant Variables } \\
\text { (variable with value T Test < 0.000) }\end{array}$ & Durbin Watson \\
\hline Whole sector & $44,29 \%$ & 0.007148 & BETA, INFL & 1.9983 \\
Various Industry & $38,96 \%$ & 0.000934 & EXCR & 1.8700 \\
Consumption goods Industry & $30,38 \%$ & 0.000005 & INTR & 1.2383 \\
Basic Industry and Chemistry & $55,47 \%$ & 0.000003 & EXCR & 1.2168 \\
Utilities and Transportation Infrastructure & $31,01 \%$ & 0.004361 & BETA & 2.0027 \\
Finance & $71,23 \%$ & 0.005203 & EXCR & 1.9233 \\
Trade, Service and Investment & $30,68 \%$ & 0.000036 & EXCR & 1.6092 \\
Mining & $43,23 \%$ & 0.000375 & BETA & 1.9226 \\
Agriculture & $38,76 \%$ & 0.000654 & BETA & 1.9914 \\
Property and Real Estate & $48,12 \%$ & 0.000036 & INTR & 1.9243 \\
\hline
\end{tabular}

\section{DISCUSSION OF RESULTS}

Based on result of the regression of each industrial sector, it is found that systematic risk has significant influence in estimating stock return for agricultural, mining and infrastructure sector. Sectors that control public needs and have specific buyers (such as fisheries, agricultural products, and mining products) make them have characteristics in their respective businesses. Changes in composite stock price index and other non-systematic risk factors will make company's characteristics reflect their stock returns. Moreover, exchange rates have a significant effect on the basic industrial sectors of chemistry, various industry, financial and service trade, and investment sector. In these industrial sectors, raw material required doesn't come directly from the origin country of the company. The purchase of financial services, chemical and other industries for trade needs makes the currency influence the operation of these sectors' issuers. The interest rate has a significant effect on the industrial sector of consumption goods and real estate property. In these industrial sectors, interest is the driving force because these sectors are a type of sector requiring loan funds to expand or pay suppliers, so the performance of their stocks is influenced by the interest rate.

The findings of this study confirm the empirical test results of macroeconomic and systematic risk variable on stock returns. Simultaneously, this research shows that inflation, interest, and exchange rate variable significantly influence the composite stock price index (Dodi, 2014). Inflation is assumed that it has negative influence towards Indonesia Composite Index (Nyoman, 2014) because the rising price will cause Indonesia Composite Index declines in purchasing power and stock fluctuation. The existence of independent variable besides macroeconomic in research model also shows that inflation, deposit interest rate, and stock trading volume have positive effect to stock return (Mirza and Nasir, 2011; Sutrisno, 2017; Indriastuti and Nafiyah, 2017; Ikkoku and Hosseini, 2008; Oshaibat, 2016; Majid, 2010). However, the results of this study show different things from other studies (Linzzy, 2017; Arika and Soedarsa, 2016) showing that macro-economy in this research has no effect on stock returns.

The volume of stock trading in this study is recognized to be closely related to the stock return. Associated with the theory of market efficiency (Fama, Eugene and French, 1988), the demand for an issuer's stock will lead to demand that increases price and return the stock. From the volume of trade and theory of market efficiency, the positive relationship between stock return and beta is explained based on Capital Asset Pricing Model theory. In equilibrium condition, stock return increases along with the increasing constant of beta or non-systematic risk.

In each specific sector, non-systematic risk, inflation, exchange rate, and interest have influence on stock return. The effect of exchange rates on trade, service, and investment sector and basic chemical industrial sector is along with a research in one of specific example on hotels subsector in 2012 to 2013 (Artini et al, 2015; Tommy and Mahilo, 2015). In hotels subsector, exchange rates negatively affect returns, while company's profitability variable positively affects return. Moreover, the interest rate positively affects return in 28 banking corporates in 2006 to 2008 (Mirza and Nasir, 2011) because the rising interest rate becomes conventional instrument to determine the value of stock in the future. The level of investment will be higher if the interest rate is high because the rate of return expected by investors will 
increase from the rising interest. Furthermore, other non-economic factors, such as market reaction towards a particular event can also be a reference in determining stock return of other macro and microeconomic variables (Barus and Christina, 2014).

\section{CONCLUSION}

Based on the effect of economic condition in Indonesia and on the data collected by the writer, it is found that macro economy measured using consumer price index inflation, exchange rate of Rupiah towards United States Dollar, JIBOR interest rate, and systematic risk or beta stock of a company simultaneously affect the company's stock return in all industrial sectors. This study shows that variety of industrial sectors reach its stock return which can be estimated about $44.29 \%$ by macroeconomic factors. Then, for future research, the writer suggests the future writers to use non-systematic risk and other variables to show research models, such as: 1) the risk of each industrial sector; 2) Non-economy variables, such as management and corporate governance involving public ownership and managerial participants, and 3) Financial ratio reflecting the characteristics of each company.

\section{REFERENCES}

1. Adityara, E. (2012). The Influence of the World Stock Market Against Indonesia Stock Market (Pengaruh Pasar Saham Dunia Terhadap Pasar Saham Indonesia). UIN Syarif Hidayatullah Jakarta. Journal Etikonomi Vol 11. No. 2.

2. Ahmad, A. A. \& Halim A. A. (2014). The Concept of Hedging in Islamic Financial Transactions. Asian Social Science; Vol. 10, No. 8; 2014. Canadian Center of Science and Education

3. Anggrahini, D. P. \& Priyadi M. P. (2016). The Effect Of Financial Performance And Growth Opportunity To Stock Return (Pengaruh Kinerja Keuangan Dan Growth Opportunity Terhadap Return Saham). Journal Science and Accounting Research: Volume 5, Nomor 3, Maret 2016.

4. Artini, L. G. S., Wiksuana, I. G. B., Eka P. E. (2015). The Effect of Rupiah Exchange Rate on Stock Return with Profitability as Intervening Variable (Pengaruh Nilai Tukar Rupiah terhadap Return Saham dengan Profitabilitas sebagai Variabel Intervening). Article E-Journal Economics and Business University Udayana.

5. Bagi. (2017). Inflation in Indonesia (Consumer Price Index). Citing Internet sources URL https://www.indonesia-investments.com/id/keuangan/angka-ekonomi-makro/inflasi-di-ind onesia/item254? Access date August 1, 2017.

6. Barus, A. C. \& Christina. (2014). The Influence of Market Reaction To The Stock Price of Companies Listed In Indonesia Stock Exchange (Pengaruh Reaksi Pasar Terhadap Harga Saham Perusahaan Yang Terdaftar Di Bursa Efek Indonesia). Journal Wira Ekonomi Mikroskil Volume 4, Nomor 01, April 2014.

7. Cooper, I. et al. (2013). The Effect of Investor Sentiment on Stock Returns in Norway and Vietnam. Journal BI Norwegian Business School. Oslo University, Norwegia.

8. Darmadi, B. (2011). Land Transport Vehicles Grow 20\% (Kendaraan Angkutan Darat Tumbuh 20\%). Citing Internet sources URL http://www.kemenperin.go.id/artikel/4649/. Access date August 1, 2017.

9. Deitiana, T. (2011). The Influence of Financial Ratio, Growth Of Sales And Dividend To Stock Price (Pengaruh Rasio Keuangan, Pertumbuhan Penjualan Dan Dividen Terhadap Harga Saham). Journal of Business and Accounting Vol 13. No. 1 April 2011. p56-66.

10. Dodi, A. (2014). Influence of Gross Domestic Product, Total Money Supply, Inflation and BI Rate Against Indonesia Composite Stock Price Index Period 2007 - 2013. Journal of Scientific Business Economics. Volume 19 No. 3 December 2014.

11. Fama, Eugene \& French K. (1988). Permanent and Temporary Components of Stock Prices, Journal of Political Economy No. 96. p246-273.

12. Fama, Eugene \& French K. (1989). Business Conditions and Expected Returns on Stocks and Bonds. Journal of Financial Economics No. 25. p23-49. 
13. Fama, Eugene \& Schwert G. W. (1977). Asset Returns and Inflation. Journal of Financial Economics Vol. 5. pp. 115-146.

14. Ginting, S. (2011). Influence Analysis of Cash Flow Growth and Profitability to Return of Stock at LQ-45 Company in Indonesia Stock Exchange. Journal of Economic Wira Mikroskil 2012 Indonesia. Volume 1, No. 02, Oktober 2011.

15. Gujarati, D.N. (2004). Basic Econometric (4th Ed.). The McGraw-Hill Companies. NewYork. p28.

16. Gunawan, H. (24 Januari 2014). Land transportation growth this year only $4 \%$ (Pertumbuhan transportasi darat tahun Ini cuma 4\%). Citing Internet sources URL http://industri.kontan.co.id/news/ Access date August 1, 2014

17. Ikoku, A. \& Hosseini, A. (2008). The Comparative Performance of African Stock Markets: Nominal, Real And U.S. Dollar Returns. International Journal of Business 13(3), 2008.

18. Indayani \& M. Nur Yahya. (2013). The Influence of Cash Position, Debt Ratio To Equity, And Growth Potential Of The Dividend Distribution Ratio In Manufacturing Companies Listed In Stock Exchange (Pengaruh Posisi Kas, Rasio Utang Terhadap Ekuitas,Dan Potensi Pertumbuhan Terhadap Rasio Pembagian Dividen Pada Perusahaan Manufaktur Yang Terdaftar Di BEI). University Syiah Kuala. Journal Etikonomi Vol. 12 No. 1 April 2013

19. Indriastuti, A. \& Nafiah, Z. (2017). The Effect of Trading Volume, Exchange Rate And Market Risk Against Stock Return (Pengaruh Volume Perdagangan, Kurs Dan Risiko Pasar Terhadap Return Saham). Journal STIE Semarang Vol 9 No. 1 Edisi Februari 2017.

20. Jacobs, P. (2013). July Peak Inflation 2013. Press Release Communications Department. Citing Internet sources URL http://www.bi.go.id/id/ruang-media/ Access date August 1, 2017.

21. Jemmy, H. (2012). Stock Overreaction Analysis of Basic and Chemical Industrial sector In Indonesia Stock Exchange Period 2006-2011. Published Thesis. University of Indonesia Faculty of Economics.

22. Jogiyanto. (2003). Portfolio Theory and Investment Analysis Third Edition (Teori Portofolio dan Analisis Investasi Edisi Ketiga). Yogyakarta:BPFE-Yogyakarta.

23. Kiem, D. B. \& Stambaugh, R. F. (1986). Predicting Returns In The Stocks And Bond Markets. Journal of Financial Economics 17 (1986) p357 - 390 North Holland.

24. Kompas. (2008). Inflation Rate 33 Cities Above National Inflation. URL http://lifestyle.kompas.com/read/2008/07/25/21101598 Access date August 1, 2017.

25. Kothari, S.P. \& Shanken J. (1997). Book To Market, Dividend Yield, and Expected Market Returns: A Time Series Analysis. Journal of Financial Economics No. 44. p169-203.

26. Kusmawati. (2011). The Influence Of Motivation Of Interest In Investing In The Capital Market With The Understanding Of Investment And Age As Moderate Variables (Pengaruh Motivasi Terhadap Minat Berinvestasi Di Pasar Modal Dengan Pemahaman Investasi Dan Usia Sebagai Variabel Moderat). STIE Musi Palembang. Journal of Economics And Accounting Information Vol. 1 No. 2 Mei 2011.

27. Lewellen, J. W. (2000). Predictability of Stock Returns: Theory and Evidence. School of Business Administration. University of Rochester Rochester, New York

28. Linzzy, P. P. (2017). Influence of Inflation and Rupiah Exchange Rate on US Dollar on Stock Performance of Property and Real Estate Companies in Indonesia (Pengaruh Inflasi dan Nilai Tukar Rupiah Atas Dollar AS terhadap Kinerja Saham Perusahaan Property dan Real Estate di Indonesia). Journal Ekonomikawan: Journal of Economic Science and Development Studies Vol 17, No 12017.

29. Maga, Y.L.V., Tommy, P. \& Tulung, J.E. (2016). Analys Of Capital Structure, Profitability, And Assets Structure Of Stock Value In Tekstil And Garment Company Listed In Indonesia Stock Exchange Period Of 2011-2014. Artikel Jurnal Riset Ekonomi, Manajemen, Bisnis Dan Akuntansi Vol.4 No. 3 September 2016, p411-421.

30. Majid. M. S. A. (2010) Stock Returns, Economic Activity And Inflationary Trends In Malaysia: Evidence From The Post-1997 Asian Financial Turmoil. The IUP Journal Of Applied Finance, Vol. 16, No. 3, 2010.

31. Merawati, L. K. \& Putra, J. S. (2016). Impact of Capital Market Training on Investment Knowledge and Student Investing Interest (Dampak Pelatihan Pasar Modal Terhadap 
Pengetahuan Investasi Dan Minat Berinvestasi Mahasiswa). Journal Accounting Prodi Faculty of Economics LPPM University Mahasaraswati, Denpasar.

32. Mirza, A. \& Nasir, A. (2011). Influence of Exchange Rate, Inflation, Deposit Interest Rate and Stock Trading Volume to Return of Stock at Banking Company Registered at Indonesia Stock Exchange (Pengaruh Nilai Kurs, Inflasi, Suku Bunga Deposito dan Volume Perdagangan Saham terhadap Return Saham pada Perusahaan Perbankan yang Terdaftar di Bursa Efek Indonesia). Jurnal Ekonomi University Riau Vol 19, No 042011.

33. Murtianingsih. (2012). Macroeconomic Variables And Composite Stock Price Index (Variabel Ekonomi Makro Dan Indeks Harga Saham Gabungan). Journal of Management and Accounting Desember Vol 1 No.3 tahun 2012. p3.

34. Mutiara, M. (2012). Stock Portfolio Return Analysis Based on Mispricing Level (Analisis Return Portofolio Saham Berdasarkan Tingkat Mispricing). Thesis. Faculty of Economics University Indonesia. Depok. p8.

35. Nachrowi, N. D. \& Usman, H. (2006). A Popular Approach and Practical Econometrics For Economic and Financial Analysis (Pendekatan Populer dan Praktis Ekonometrika Untuk Analisis Ekonomi dan Keuangan). Jakarta: Lembaga Penerbit Faculty of Economics University Indonesia. p10.

36. Nasution, M.E., \& Usman, H. (2007). Quantitative Research Process (Proses Penelitian Kuantitatif). Jakarta: Lembaga Penerbit FEUI. p13.

37. Nelvianti, N. (2013). The Influence of Cash Flow Information, Profit And Company Size Against Abnormal Return of Shares In Manufacturing Companies Listed In Indonesia Stock Exchange (Pengaruh Informasi Arus Kas, Laba Dan Ukuran Perusahaan Terhadap Abnormal Return Saham Pada Perusahaan Manufaktur Yang Terdaftar Di Bursa Efek Indonesia). Accounting Journal Vol 2. Tahun 2013.

38. Nurhayanto. (2011). Market Risk Analysis Portfolio Investment Shares With Value At Risk Method (Case Study At RST Pension Fund) (Analisis Risiko Pasar Portofolio Investasi Saham Dengan Metode Value At Risk (Studi Kasus Pada Dana Pensiun RST)). Unpublished Thesis. Faculty of Economics Indonesian University. Depok. p11.

39. Oshaibat, S. A. (2016). The Relationship Between Stock Returns And Each Of Inflation, Interest Rates, Share Liquidity And Remittances Of Workers In The Amman Stock Exchange. Journal Of Internet Banking And Commerce, August 2016, Vol. 21, No. 2

40. Pangemanan V. (2013). Inflation, Exchange Rate, Interest Rate Against Systematic Risk In Sub-Sector Company Food And Beverage At BEI (Inflasi, Nilai Tukar, Suku Bunga Terhadap Risiko Sistematis Pada Perusahaan Sub-Sektor Food And Beverage Di BEI). Journal of Economic Research, Management, Business and Accounting Vol.1 No.3 September 2013. p189-196.

41. Rahmawati, F. I. \& Handayani, S. R. (2017). The Influence Of Good Corporate Governance Practice On The Stock Price (Study On Company Of Lq45 Index In Indonesia Stock Exchange During 2012-2016). Journal of Business Administration Vol. 50 No. 6 September 2017. p164.

42. Sarumaha, A. (2015). Analysis of Macroeconomic Influence And Fundamental Factor Of Companies On Stock Beta In Mining Industry Registered In Indonesia Stock Exchange (Analisis Pengaruh Makro Ekonomi Dan Faktor Fundamental Perusahaan Terhadap Beta Saham Pada Industri Pertambangan Yang Terdaftar Di Bursa Efek Indonesia). E-Journal Widya Ekonomika 2015. p104.

43. Sharpe, Alexander \& Bailey, (2005). Investment. Intermasa Jakarta. Edisi enam Jilid 1.

44. Soedarsa, H. G. Arika \& Prita, P. R. (2016). Influence of Inflation Rate, GDP Growth, Company Size, Leverage, and Profitability to Share Price at Property and Real Estate Sector Companies Listed on Indonesia Stock Exchange Period 2005-2013 (Pengaruh Tingkat Inflasi, Pertumbuhan PDB, Ukuran Perusahaan, Leverage, dan Profitabilitas terhadap Harga Saham pada Perusahaan Sektor Properti dan Real Estate yang Terdaftar di Bursa Efek Indonesia Periode 2005-2013). Jurnal Akuntansi dan Keuangan University Bandar Lampung. Journal of Accounting and Finance Vol. 7, No. 1, March 2016. p87-102.

45. Steven, M. (28 Mei 2013). Indonesian Capital Market Still Holds Negative Sentiment (Pasar Modal Indonesia Masih Tahan Sentimen Negatif). Citing Internet sources URL 
www.republika.co.id Access date August 1, 2017.

46. Sugema, I. (2012). Global Financial Crisis 2008-2009 And Its Implications In Indonesia's Economy (Krisis Keuangan Global 2008-2009 Dan Implikasinya Pada Perekonomian Indonesia). Journal of Agricultural Science of Indonesia, Desember 2012 Vol.17 (3): 145-152

47. Suherni, F. (2015). Influence of Cash Flow and Profit Growth on Stock Return on Manufacturing Companies Listed In Indonesia Stock Exchange 2008-2013 (Pengaruh Arus Kas Dan Pertumbuhan Laba Terhadap Return Saham Pada Perusahaan Manufaktur Yang Terdaftar Di Bursa Efek Indonesia 2008-2013). Electronic Journal; Faculty of Economics UMRAH 2015

48. Sulistio T. (2016). Foreign Investors Take Control of Indonesian Market? (Investor Asing Kuasai Pasar Indonesia?) Citing Internet sources URL www.viva.co.id Access date August 1, 2017.

49. Sutrisno, B. (2017). Relationship Volatility And Trading Volume In Indonesia Stock Exchange (Hubungan Volatilitas Dan Volume Perdagangan Di Bursa Efek Indonesia). Journal of Business and Management Volume 7(1), April 2017. p15-26.

50. Tjahjono et. al. Team Biro Riset Ekonomi. (14 April 2009). Outlook Ekonomi Indonesia 2009 - 2014 : The Global Financial Crisis and Its Impact on the Indonesian Economy (Krisis Finansial Global dan Dampaknya terhadap Perekonomian Indonesia). Citing Internet sources URL http://www.bi.go.id/id/publikasi/ Access date August 1, 2017.

51. Tommy, P. \& Mahilo, M. B. (2015). Influence of Interest Rate Risk, Inflation, and Exchange Rate on Return of Food and Beverage Company Shares Go Public in Indonesia Stock Exchange (Dampak Risiko Suku Bunga, Inflasi, dan Kurs terhadap Return Saham Perusahaan Makanan dan Minuman yang Go Public di Bursa Efek Indonesia). Journal of Economic Research, Management, Business and Accounting 1 Vol.3 No.3 Sept. 2015, p1-10.

52. Uluipuli, I G. K. A. (2007). Influence Analysis of Liquidity Ratio, Leverage, Activity, And Profitability To Stock Return (Study On Food And Beverage Company With Consumption goods Industry Category In JSE) (Analisis Pengaruh Rasio Likuiditas, Leverage, Aktivitas, Dan Profitabilitas Terhadap Return Saham (Studi Pada Perusahaan Makanan Dan Minuman Dengan Kategori Industri Barang Konsumsi Di BEJ)). Journal of Accounting and Business Sciences.

53. Yague, J. C. \& Gomez, J. (2005). Price and Tick Size Preferences in Trading Activity Changes Around Stock Split Executions. Spanish Economic Review Rev 7. pp. 111-138. 